\title{
An Analysis of Figurative Language in Harmony's Song Lyrics
}

\author{
Kiki Ariska ${ }^{1)}$, Syamsurrijal ${ }^{2)}$, Wahyu Kamil Syarifaturrahman ${ }^{3)}$ \\ ${ }^{1}$ Universitas Bumigora \\ Kikiariska2905@gmail.com \\ ${ }^{2}$ Universitas Bumigora \\ rijalhalilintar@gmail.com \\ ${ }^{3}$ Universitas Bumigora \\ wahyu.kamil@universitasbumigora.ac.id
}

\begin{abstract}
Received: $17^{\text {th }}$ November 2021| Revised: 14th December 2021| Accepted: 17th December 2021
Email Correspondence: wahyu.kamil@universitasbumigora.ac.id
\end{abstract}

\begin{abstract}
The purposes of this research are: (1) to identify the types of figurative language found in Harmony's song lyrics. And (2) what are the function of figurative language used in Harmony's song lyrics? This research applied descriptive qualitative approach. In collecting the data, the researcher searched the songs and noting technique to the scripts. Read and understood the song lyrics in Harmony's song lyrics. While in analyzing the data, the researcher translate the data into English, identified the data based on the types of figurative languages, classified the data based on the types of figurative languages, analyzed the selected data based on the figurative languages. The results of data analysis, there are seven data found in Harmony's song lyrics, namely: simile, symbol, irony, personification, paradox, hyperbole, and metaphor. The function of figurative language simile and symbol in Thun Nathe's song lyrics is to afford imagination pleasure, while in irony is to add emotional intensity. In Sauadagar Percek's song lyrics simile is used to afford imaginative pleasure, personification and paradox is used to say much in a brief compass, while in hyperbole is to add emotional intensity. In Selaq Bonga's song lyrics, metaphor is used to add emotional intensity.
\end{abstract}

Keywords: figurative, song, and lyrics

\section{INTRODUCTION}

In daily life, language is one of the important things exists on human's life. According to Kreidler (2013) "language is a system of symbols through which people communicate". From statement above it need to be realized that language just a tool to communicate each other and to express our idea, intention, etc.

Language as tool of communication is used by group of people in a society to communicate each other. In expressing their ideas, every people have their own strategy, one of them is literature. According to Meyer in Cindy ( 2019), "Literature is a term used to describe written texts marked by careful use of language, including features such as creative metaphors, well-turned phrases, elegant syntax, rhyme,

Online at https://journal.universitasbumigora.ac.id/index.php/humanitatis/

DOI : https://doi.org/10.30812/humanitatis.v8i1.1562 
alliteration, which are aesthetically read or intended by the author to be aesthetically read and are deliberately somewhat open in interpretation. Song is one example of literature".

Actually many forms of literatures, one of them is the song. Song is one of the familiar literatures in our society. According to Jamalus in Nisa (2020) stated that songs can be described as art works in singing to musical instruments accompaniment. In addition, Hornby (2020: 22) defined song as a short rhyme or set of verses in music and aimed to be sung. Based on the explanation above, it can be concluded that the song is one of the literature in the form of poem which is showed by sung and accompanied by musical instruments.

Actually, in the song lyrics, many aspects can be analyzed by the researcher. Some of those aspects that can be analyzed in the song lyrics are, translations techniques, ambiguities of lyrics, use of figurative languages, etc. Those aspects are reasonable to be analyzed. From all of the aspects that can be analyzed in the song lyrics, and this research focus in analyzing the figurative language in Harmony's lyric songs.

When listening a song some people may not focus on the lyrics used in the song, especially if the song contains figurative element. There is hidden meaning in song lyrics. Song lyrics use uncommon words, compared to the word used in daily conversation. The lyrics use the figurative language to create its own meaning itself; if we can interpret its meaning deeper. While the listeners know the meaning of the lyrics, they will have their own opinion. Therefore, people will interpret it by their understanding without knowing the truth or conformity with the purpose of a composer. Beautiful words will have valuable meanings and require ability to deliver ideas through figurative language in song lyrics.

Furthermore, the researcher discusses Harmony's song lyrics, and the meaning of Harmony;'s song lyric. There are three title's lyrics of Harmony's song focused to analyse in this study namely; Thun Nathe, Saudagar Percek, and Selaq Bonga as the object of the study for some reasons; first, Harmony has become a phenomenon in North Lombok and gained much love and attention from the society. Secondly, songs sometimes contain difficult words which cannot find those meaning literally because the language that it used is local language in North Lombok, so the researcher needs deep interpretation and translete technique to understand what is the meanings or messages that the songwriter tries to convey to the listeners.

One of the theories was used in analyzing in this study namely stylistics which is the new discipline discovered at the beginning of the 20th century by Charles Bally. The literary stylistics

Online at https://journal.universitasbumigora.ac.id/index.php/humanitatis/

DOI $\quad$ : https://doi.org/10.30812/humanitatis.v8i1.1562 
considers with style while the linguistics reckons with the affective elements from the spoken language or utterances Kadir and Saraab in Syahrina (2019).

Stylistics on its development, had expanded the objects of the study. At first, stylistics is used to investigate the literary works. Stylistics is one of the critical approach of linguistics in the analysis of literary texts. The linguistic here is meant the scintific study of language and the structures, not the learning of individual or certain people's language. The aims of stylistics is to depict how the linguitsics features in a literary work, such as the grammatical feature, figurative language, phonological schemes that support to the whole effects. In addition, stylistics is not not also limited to the literature analysis, it can be applied to other corpus such as political speeches, advertisments, and etc. (Syahrina, 2019).

Acoording to Barry in Syahrina (2019), "Stylistics is the study of the ways which its meaning is created through language in literature as well as in orther types of text. Some stylistic analysis mainly focuses qualitatively or quantitatively on the phonological, lexical, grammatical, semantic, pragmatic, or discoursal features of text. Many researcher more focus on the text itself rather than knowing the procedure, investigating the style of the author. Other than any branches in the literary criticism, stylistics approach to the text analysis might seem more objective. It has been proven that it can provide beneficial tool and methods which enable the researcher to cunduct the analysis in which meaning is created in texts by linguistic means".

According to Barry in Syahrina (2019) "Stylistics approach in literature is to show how the linguistic features involved in a literaty work. Stylistic, linguistic element, is able to be called as one way ti critize the literary work. The stylistics study mainly focueses on the textual analysis and its technical usage in literaty text such as poetry, short story, song lyrics, novels, etc".

There are four categories of the stylistics study. They are the lexical categories, grammatical categories, figures of speech, and context and cohesion. Lexical categories is used to investigate how choice of words involved in various types of meaning. Lexical stylistics reckons with the style that concerns about word choice. In text, there are such as types of lexical categories which are noun, pronoun, verb, adverb, adjective, preposition, conjuction and interjection. Grammatical categories deals with the sentence types such as declarative sentence structure by analysing it through the sentence types such as declarative sentence, questions, and commands or imperative (Leech and Short in Syahrina, 2019).

The figures of speech is one of the stylistics feature that foreground by virtue of departing in some way from general norms of communication by means of the language code. Figures of speech is the forms of speech which distinguish from common speech in use. By the use of figures of speech, language

Online at https://journal.universitasbumigora.ac.id/index.php/humanitatis/

DOI : https://doi.org/10.30812/humanitatis.v8i1.1562 
becomes figurative. Last, context and cohesion also have its own significant role which can be analysed through the stylistic study. Cohesion is defined as the ways in which the sentences are connected, while context is defined as the external relations of a text or part of a text. Context is seen as a discourse by presupposing a social relation between its participants (Leech and Short in Syahrina, 2019).

According to Perrine in Indratno, (2020) "figurative language is language whichuses a non-literal meaning. Figurative language is usually applied to express what people want to deliver in different way. Figurative meaning invites people to think broader from what it is written. Figurative language is usually used by the authors of literary work to deliver what they thought of".

Figurative language is divided into some types. Perrine divided figurative language into 10 (ten) They are metaphor, simile, personification, metonymy, symbol, allegory, paradox, hyperbole, understatement, and irony" (Perrine in Indratno, 2020). The researcher uses Perrine's theory since it has more variations which can help the researcher to analyze the data.

Metaphor is used to compare between things that are different. According to Perrine in Indratno (2020), "in metaphor one thing represents another thing which is inanimate. Perrine states that between metaphor and simile is similar. Both of which are comparison between two things that are essentially unlike. The only distinction between them is the use of connective words. In simile, the poet uses the connective word such as: like, as, than, similar to, resemble or seems; while in metaphor the comparison is implied; the figurative term is substituted for or identified with literal term".

Example: "White rose is a dove, red rose is a falcon

Simile and metaphor genuinely have an identical definition. Both of them compare two things that are absolutely different. Simile is a figure of speech that compares one thing to the others (Perrine in Indratno, 2020). "Simile is the comparison of two things, by the use of some words or phrase such as like as, than, similar to, or resemble".

Example: "Your eyes like a star"e

Personification is inanimate thing given the attributes of a human being (Perrine in Indratno, 2020). In personification, people can see that non-human things seem like doing human's activity.

Example: "The sunrise smiling with me"

Metonymy is figure of speech that substitute the detail of an experience for the experience itself." (Perrine in Indratno, (2020). Shortly, metonymy is the use of word that is used to represent another word. Metonymy replaces another name of thing that is closely related with it

Example: "Dony was washing him Jazz"

Symbol is defined as something that has more meaning when what it is (Perrine in Indratno,

Online at https://journal.universitasbumigora.ac.id/index.php/humanitatis/

DOI : https://doi.org/10.30812/humanitatis.v8i1.1562 
(2020). Symbol can engage people to think deeper since it has more than its meaning".

For example: symbol of flag, it represent of nation.

Allegory is defined as the narrative or description that has more than meaning (Perrine in Indratno, (2020). The purpose of allegory is to teach or explain an idea or a principle. Therefore, in allegory, people can find the moral point inside the text. Allegory is a description that has another meaning. The meaning beneath is different from its description".

Example: "The Tortoise and The Hare"

Paradox is the apparent contradiction in a statement (Perrine in Indratno, (2020). Paradox is the statement seemingly self-contradiction or opposed to what is commonly held to be true but which nevertheless contains a truth".

Example: "She feel alone in center of town"

According to Perrine in Indratno, (2020) "Understatement is the opposite of hyperbole. Understatement is used to give less than the means. Understatement reduces the expectation from what readers think in a term.

Example: Swimming with those starving sharks might be a bit unpleased.

Irony is a figure of speech that is used to tell meaning that beyond extend (Perrine in Indratno, (2020). Irony is usually used to imply the statement in the term but it is wrapped in valuable sentence". Irony is figure of speech that can be used todevelop our critical thinking and it can be sentimental when it is delivered as a statement (Aprilianingrum, 2019, p. 14).

Example: "your rapport is very good, until red color all"

According to Perrine in (Prawiro, 2019) "figurative language is used to afford imaginative pressure, to bring additional imagery, to add emotional intensity, and to say much in a brief compass".

Song is one of the familiar literatures in the listener's ear. According to Jamalus in (Nisa, 2020) reveals that songs can be described as art works in singing to musical instruments accompaniment. In short, song is a composition of voice or voices contained words, phrases and sentences created by human which is usually followed by a music.

Furthermore, lyrics are expressing a person's personal feeling and thoughts, connected with singing and written for a lyric poem is the words of a song (Hornby in Nisa, 2020: 24). It means, lyrics are expressing someone's feelings which are then written into a lyric. Language song really is not much changed from the language of poetry. It is a short lyric poem that expresses emotion. Song lyrics are poetry that singing. Form of emotive expressions is realized in sounds and words. Language in the song lyrics has rules that are elements of poems emotive through sounds and words. In addition to get a

Online at https://journal.universitasbumigora.ac.id/index.php/humanitatis/

DOI : https://doi.org/10.30812/humanitatis.v8i1.1562 
particular impression as poetry, language lyrics are concise and packed. This is explained by the lyrics of the song has undergone a process of compaction of meaning and creativity diction of election poet".

According to (Nisa, 2020) "Lyrics are a set of words that make up a song. Usually consisting of verses and choruses. The meaning of lyrics can either be explicit or implicit. Some lyrics are abstract, almost unintelligible, and, in such cases, their explication emphasizes form, articulation, meter, and symmetry of expression. A lyric is a paper written by someone who has imagination in composing beautiful words that have deep meaning. Lyrics and music combined would be a very good song and pleasing to the ear. The writer of lyrics is a lyricist or lyrics".

Based on the statement above the researcher concludes that lyric is a part of literature, because lyric demonstrate the song author's lives itself.

\section{RESEARCH METHOD}

This research, used descriptive- qualitative method. According to (Kothari, 2004), descriptive research include surveys and fact-finding inquiries of different kinds. He also believes that the main characteristics of descriptive method is that the researcher has no control over the variables, the researcher can only report what has happened or what is happening. All the data are taken from Harmony's song which focus on 3 (three) title's lyric (Thun Nathe, Saudagar Percek, and Selaq Bonga) analyzed descriptively by explaining the example based on Perrine's theory.

The data of this research is collected from Harmony's song. The process of data collection itself is started from watching the video, then the researcher downloaded the video and took a note of the song's lyric as the data. Then the researcher attempted to find the word, phrase, and sentence which contain figurative language and anylize the meaning of each figurative language. Finally, the researcher classified it and rechecks the data and ready to analyze it.

After the data have been obtained from data sources, the data will analyze through the following procedure: Reading and identifying the whole lyrics to find figurative language, Classifying the lyrics to find the types of figurative language based on Perrine's theory, Transleting the data literally into English, and Analyzing the meaning of figurative language in the lyrics based on Perrine's theory.

\section{FINDINGS AND DISCUSSION}

This Harmony is one of the local bands in North Lombok. The song appear before the general election or the end of the term of office is coming to an end. This is proven because of the regent election on February 2020. And the first song is published on October 2019 that is Thun Nathe song. The second song is Saudagar Percek on October 2020. While third song is Selaq Bonga is published on December

Online at https://journal.universitasbumigora.ac.id/index.php/humanitatis/

DOI : https://doi.org/10.30812/humanitatis.v8i1.1562 
2020. In Harmony's song lyrics, there are 10 data that contains figurative language. In Thun Nathe's song lyrics there are simile (one data), symbol (one data) and irony (one data). In Saudagar Percek's song lyrics there are simile (two data), personification (one data), paradox (one data), and hyperbole (two data). Then, in Selaq Bonga's song lyrics there is only metaphor (one data).

\subsection{Figurative Language in Thun Nathe's Song lyric}

Thun Nathe song is the first data analyzed in this research. In Thun Nathe song, there are 18 lines of the lyrics song. There are three lyrics song that contains figurative languages. Furthermore, the researcher decided 2 (two) lyrics as the data and then the data classified into 3 (three) categories They are simile, symbol, and irony.

\section{Pelampan marak sisoq lambat $\underline{\text { menggoyan }}$}

character like snail slow to work

The way to walk like a snail, working slaowly.

2. $\underline{\text { Batur }} \underline{\text { wah dait }} \underline{\text { Jerman }} \underline{\text { ita }}$ masih ngerongan

Friend has get Germany we still stay

Many of our friends have been arrived in Germany, but we have no movement

From the data 1, it found the Simile category which is the first figurative language found in Thun Nathe's song lyrics. The simile found in Thun Nathe song goes to the lines 9, in 18 lyrics song. "Simile is a figure of speech that compare one things to other (Perrine in Indratno, (2020)". It contains simile because the simile can be seen in sentence "the way to walk like a snail". This sentence uses the word 'like' as a linking verb in the lyric which become characteristic of simile category. In the lyric above the literal meaning of snail is one of the names of animal and the characteristic of the snail is extremely slow animal which means it sluggish. The figurative meaning is the sentence represents the person's life which means they do not have passion. The sentence above equalizes the people like a snail. In short, the meaning in sentence above is they can't work nimbly. They try to convey that those people incompetent at work. So that, the function of this figurative language is to afford imaginative pleasure. It is because the first expression contain figurative language that can be detected from the word "like", and it is does not mean that the way to walk like a snail. By using the word "the way" and "snail" automatically evoke the reader or listener imagination which means that how sluggish they are.

The second category of figurative languages found in Thun Nathe's song lyrics is symbol. There is one symbol that found in these lyrics. The symbol comes from lines 9. In the lyric above symbol can be seen in snail and explain by the next sentence slow at work. Snails are animal that charcterized by their

Online at https://journal.universitasbumigora.ac.id/index.php/humanitatis/

DOI : https://doi.org/10.30812/humanitatis.v8i1.1562 
slow movements. the lyrics above clarify people's skill in scope of work. Therefore, the function of this figurative language is to afford imaginative pleasure. It is because the first expression contain figurative language that can be detected from the word "like", and it is does not mean that the way to walk like a snail. By using the word "the way" and "snail" automatically evoke the reader or listener imagination which means that how sluggish they are. By making comparison between characteristics of people's way and the characteristics of animal as an imagery.

The last category of figurative language found in Thun Nathe's song lyrics is Irony. As mentioned in chapter two "Irony is a figure of speech that is used to tell meaning that beyond extend (Perrine in Indratno, (2020). Irony usually used to imply the statement in the term but it is wrapped in valuable sentence. The lyrics that contains irony comes from lines 6 (six), it can be seen in data 2 (two) above. The irony can be seen in the sentence "Friends have arrived in Germany, but we still in place". The irony can be seen when other people have arrived in Germany, but we are still in place. It shows how sluggish they are. In literal meaning Germany is quite far from Indonesia and also it is advanced country, so it takes hard work to get there. In figurative meaning, this lyrics implied that the other people have been advanced and they are still in place. The meaning stay in place is there is no change. It is marked by "The way to walk like a snail, slow at work" in lines 9 and "no changes lines 10 . We can conclude that they are left behind. The function of this figurative langue is to add emotional intensity. The irony can be seen when other people have arrived in Germany, but we are still in place. It shows how sluggish they are. This sentence give a special effect, it is touch the reader or listener feel sad because of how sluggish they are.

\subsection{Figurative Language in Saudagar Percek's song lyrics}

In this title of the song found 6 (six) lyrics as the data as follow:

\section{Saudagar percek dateng rapet pemilihan \\ Merchant lighter come near election}

The Lighter Merchant comes when the election will be held

\begin{tabular}{|c|c|c|c|c|}
\hline$\underline{S i k}$ & penting & manuk & $y a$ & menang \\
\hline Which & important & chicken & $3^{\text {rd }}$ pl.poss & win \\
\hline
\end{tabular}

The important thing is thier chiken wins

\section{Keliur peteng kelem marak bukal \\ Wondering dark night like bat \\ Midnight wandering like a bat}

Online at https://journal.universitasbumigora.ac.id/index.php/humanitatis/

DOI : https://doi.org/10.30812/humanitatis.v8i1.1562 


\section{Menginte marak tikus tundeq luan}

Leering like mouse see food

Lurking like a rat looking for side dish

\section{Mauq secerot $\underline{\text { menceret taonan }}$}

Get little diarrhea years

get a little, having diarhea for many years.

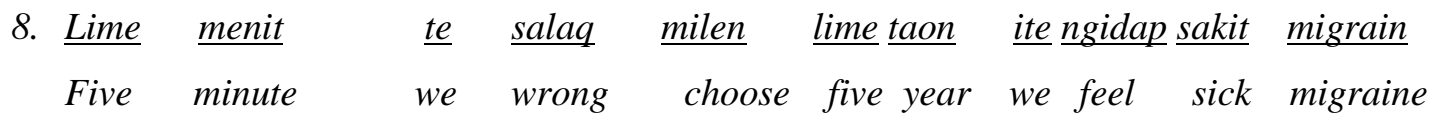

If we get wrong chosen, five years we will get migraine

In this title of the song also found 2 (two) data (see data 5 (five) and 6 (six)) above as Simile category. Actually, simile that found in this song lyrics is comes from lines 8. In sentence "lurking like a rat looking for food" and "Midnight wandering like a bat", they can be underlined the word "like" that shows the simile in the lyrics. In literal meaning the rats always lurking when they want to taking food. Therefore, in figurative meaning, in the data 5 (five) 'Midnight wandering like a bat' the phrase 'like a bat' refers to someone should do survey first in every time, if want to get the right target, which means that the people to stake out to determine whose target he will aim for. If they don't survey first, perhaps they will found wrong target, they will meet enemy of the candidate. In addition, the man and his proponents as the candidate suppose their attitude as 'a bat' mostly work in the night. Therefore, the function of this figurative language is to afford imaginative pleasure. It is because the first expression contains figurative language that can be detected from the word "like", and it is bring us to imagine slinking like a rat same as the thief.

The second figurative language used in Saudagar Percek's song lyric is personification. Personification is inanimate thing given the attributes of a human being (Perrine in Indratno, (2020). In personification, people can see that non-human things seem like doing human's activity. The lyric is found in lines 6 (six), it can be seen in data 4 (four). It is classified as the personification because the word "chicken" is an animal but it used for humans, this is indicated by the previous sentence like lines 3 , 4, and 5 that mention "money capital, wad of money", "share the thugs", and "who needs, please come closer". In literal meaning chicken is an animal. Therefore figurative meaning chicken is the people who will be the candidate in general election. Therefore, its function actually is expressing wider context in a brief compass. The composer made his idea, purposed without explaining in detail. The composer just

Online at https://journal.universitasbumigora.ac.id/index.php/humanitatis/

DOI : https://doi.org/10.30812/humanitatis.v8i1.1562 
mentioning their chicken wins. It is used to make the reader or listener interpreting the meaning inside the text implicitly.

Paradox is the apparent contradiction in a statement (Perrine in Indratno, (2020). In paradox, people can see that in a statement has contradiction possibility. In Saudagar Percek's song lyrics, paradox comes from lines 2 (see data 3 (three) 'The Lighter Merchant comes when the election will be held'. This lyric contains paradox because 'lighter merchant' usually trade in every time without depend on the situation. But in the lyric above only come when the near of election time. So it make contradiction with the true meaning. In literal meaning lighter merchant is a seller of gas lighter but in figurative meaning this word as a bribe with money politics or refer to the candidate or his/her followers. It is because supported by the next sentence in lines 2 (come when general election is about to be held) and lines 3 ( money capital, wad of money). The meaning of this lyric is opposed to what is commonly held to be true which nevertheless contains a truth. So, the function of figurative language in this sentence is to say much in a brief compass. The word "lighter merchant". It is used to make the reader or listener interpreting the meaning or idea inside the text.

Hyperbole is figure of speech that consists the exaggeration (Perrine in Indratno, (2020). Hyperbole usually exists because the authors want to tell something that makes nonsense. The hyperbole above comes from lines 15 (see data 7 (seven) and 8 (eight)). From the lyric before mentioned the election. We can't get diarhea for many years just because get little ration. So it is exaggeration. In literal meaning diarhea is loose, watery stools (bowel movements) which lasts a short time because of bacteria or virus (medlineplus.gov). but in Figurative meaning in this lyrics, diarhea is caused by get bribes from the perpetratos of money politics and it will feel pain for many years. So we can conclude that it is exaggerated. The funtion of the figurative language in this sentence is to add emotional intensity. It is explain by the word " got a little" and "diarhea for many years". the writer makes an extraordinary word to express his feeling that is scary.

Furthermore, in the data 8 (eight) showed the second hyperbole form of hyperbole. The word choosing above is a leader. Because this sentence is continuation of the previous sentence in lines 20 that said "choose the right leader" . In literal meaning a migrain is a strong headache. one period for the candidate is five years. In Figurative meaning five minutes wrong in choosing, we will suffer from migrains for five years). It means that be careful in making choices, if the choice is wrong, five years we will suffer because it is led by the wrong leader.

Online at https://journal.universitasbumigora.ac.id/index.php/humanitatis/

DOI : https://doi.org/10.30812/humanitatis.v8i1.1562 
Because this sentence is continuation of the previous sentence in lines 20 that said "choose the right leader" . it is exaggeration. Just because we choose the wrong leader we will get migrains for five years. The function of figurative language in this sentence is to add emotional intensity. The sentence "Five minutes wrong in choosing" and "we will suffer from migrains for five years". it is clear that the writer makes an extraordinary word to express his feeling that is remembering to other people to careful when make a decision.

\subsection{Figurative language in Selaq Bonga's song lyrics}

In this title of the song found one lyric as the data as follow:

9. Janji manis luean sedaq

Promise sweet more addition

Sweet promise with loafs of mix

Metaphor is used to compare between things that are different (Perrine in Indratno, (2020). In metaphor, one thing represents another thing which is inanimate. The metaphor in this sentence comes from lines 6 (see the data 9 (nine)). In literal meaning 'sweet' is a taste of food or drink. While in figurative meaning is too much promise, then metaphor can be seen from the comparison between attitude and flavor. The function of this term is to add emotional intensity. The lyric "sweet promise with a lot of mix", the composer wants to express his feeling that he is disappointed. It is sign with the word "sweet promise" and "a lot of mix" it's mean that too much word but lacking in action.

Based on the discovery of the function figurative language above, the function of figurative language simile and symbol in Thun Nathe song lyrics is to afford imagination pleasure, while in irony is to add emotional intensity. In Sauadagar Percek's song lyrics simile is used to afford imaginative pleasure, personification and paradox is used to say much in a brief compass, while in hyperbole is to add emotional intensity. In Selaq Bonga's song lyrics, metaphor is used to add emotional intensity.

\section{CONCLUSION}

From the results of data analysis, the researcher concluded that there are seven data found in Harmony's song lyrics, namely: simile, symbol, irony, simile, personification, paradox, hyperbole, and metaphor. The function of figurative language simile and symbol in Thun Nathe song lyrics is to afford imagination pleasure, while in irony is to add emotional intensity. In Sauadagar Percek's song lyrics simile is used to afford imaginative pleasure, personification

Online at https://journal.universitasbumigora.ac.id/index.php/humanitatis/

DOI $\quad$ : https://doi.org/10.30812/humanitatis.v8i1.1562 
and paradox is used to say much in a brief compass, while in hyperbole is to add emotional intensity. In Selaq Bonga's song lyrics, metaphor is used to add emotional intensity

\section{REFERENCES}

Arifah, K. (2016). Figurative Language Analysis in Five John Legend's Song [Maulana Malik Ibrahim State Islamic University of Malang]. In Islamic University of Malang. http://etheses.uinmalang.ac.id/3618/

Cindy. (2019). The Analysis of Figurative Language Used In Three Of Lady Gaga's Songs From A Star Is Born Album. Buddhi Dharma University.

Dewi, L. A. (2020). Figurative Language in Maher Zain's Song Lyrics [State Istitute for Islamic Studies of Ponorogo]. http://etheses.iainponorogo.ac.id/10310/1/SKRIPSI LAILA ALVIANA DEWI_210916084.pdf

Eagleton, T. (1996). Literary Theory (second Ed.). Blackwell Publishing. http://staffnew.uny.ac.id/upload/132299491/pendidikan/literary-theory-terry-eagleton.pdf

Indratno, G. E. (2020). Revealing the Messages Trough Figurative Language in "Firework" by Katy Perry [Universitas Santa Dharma Yogyakarta]. https://repository.usd.ac.id/36399/1/124214084.pdf

Kothari, C. . (2004). Research Methodology Methods and Techniques (Second Ed.). New Age International Publishers. https://www.cusb.ac.in/images/cusb-files/2020/el/cbs/MCCOM2003C04 (Business Research Methods)Research_Methodology_C_R_Kothari.pdf

Kreidler, C. W. (2013). Introducing English semantics, second edition. In Introducing English Semantics, Second Edition. Routledge. https://doi.org/10.4324/9781315886428

Laksita, A. N. (2017). Figurative Expression in Song Lyrics by Male and Female Song Writers [Sanata Dharma University]. https://repository.usd.ac.id/12434/2/134214074_full.pdf

Marwati, E. (2017). The Analysis of Figurative Languages Found in Song Lyrics of Taylor Swift's Album Speak Now and Its Application in Teaching Reading at Eleventh Grade of Senior ... [Muhammadiyah University]. http://repository.umpwr.ac.id:8080/handle/123456789/1137

Nisa, K. (2020). An Analysis of Figurative Language in the Maher Zain's Song Lyric [Institut Agama Islam Negeri Metro]. https://repository.metrouniv.ac.id/id/eprint/3716/1/KHOIRUL NISA $\% 28$ Student Number 1601070023\%29.pdf

Prawiro, D. A. (2019). Figurative Language in Selected Songs Lyrics of Maher Zain [Universitas Negeri Semarang]. In Universitas Negeri Semarang. lib.unnes.ac.id

Syahrina, A. (2019). A Stylistic Study of Figurative Language in Katy Perry'S Song Lyrics From Witness Album [Universitas Islam Negeri Syarif Hidayatullah Jakarta]. https://repository.uinjkt.ac.id

Wirartha, I. M. (2006). Pedoman Penulisan Usulan Penelitian, Skripsi, dan Tesis. Penerbit Andi. https://onesearch.id/Record/IOS3395.slims-2401

Online at https://journal.universitasbumigora.ac.id/index.php/humanitatis/

DOI : https://doi.org/10.30812/humanitatis.v8i1.1562 